\title{
Fig Psyllid Homotoma ficus (L.) (Insecta: Hemiptera: Homotomidae); Curtain Fig Psyllid Macrohomotoma gladiata Kuwayama (Insecta: Hemiptera: Homotomidae); and Ficus Leaf-Rolling Psyllid Trioza brevigenae Mathur (Insecta: Hemiptera: Triozidae) ${ }^{1}$
}

\author{
Alexander Tasi, Susan Halbert, and Tolulope Morawo²
}

The Featured Creatures collection provides in-depth profiles of insects, nematodes, arachnids and other organisms relevant to Florida. These profiles are intended for the use of interested laypersons with some knowledge of biology as well as academic audiences.

\section{Introduction}

Plants grown outside of their native range often benefit, at least initially, from the absence of co-evolved herbivorous insect species. Many Old-World fig species, such as Ficus microcarpa (the Indian laurel or curtain fig) and F. carica (the edible common fig), have been planted widely in North America as valued ornamental or crop species. In California, three species of specialized sap-sucking insects known as psyllids have followed introduced Ficus species from their native ranges in Europe and Asia. Homotoma ficus (the fig psyllid) was noticed first in California in 1969, and Macrohomotoma gladiata (the curtain fig psyllid)and Trioza brevigenae (the Ficus leaf-rolling psyllid) were found to be present in California in 2015 and 2016, respectively (Rung 2016, Hodel et al. 2016, 2020).
The arrival of the two most recent psyllid species has postdated the establishment of several other exotic Ficus pests in North America. Singhiella simplex (Singh) (the ficus whitefly) was found first in Florida in 2007, before its 2012 discovery in California (Ko et al. 2015), while Gynaikothrips uzeli (Zimmerman) (the weeping fig thrips) was found in Florida in 2003 and in California in 2014 (Dara and Hodel 2015). The fact that both a thrips and a whitefly could travel across the United States in a relatively short period of time suggests that one or more of the exotic psyllid species could travel in the opposite direction and become established in Florida, where they are not known to be present.

\section{Synonomy}

In zoological nomenclature, synonyms are different scientific names that pertain to the same taxon. Of the three species considered here, only Macrohomotoma gladiata has been assigned more than one scientific name. Kuwayama (1908) introduced the name Macrohomotoma gladiatum in his initial description of the species. The -um ending of "gladiatum" suggests that the gender of the genus is neuter. However, "toma" in Macrohomotoma is derived from the

1. This document is EENY-773 one of a series of the Entomology and Nematology Department, UF/IFAS Extension. Original publication date May 2021. Visit the EDIS website at https://edis.ifas.ufl.edu for the currently supported version of this publication. This document is also available on the Featured Creatures website at http://entnemdept.ufl.edu/creatures/.

2. Alexander Tasi, Entomology and Nematology Department; Susan Halbert, Florida Department of Agriculture and Consumer Services; and Tolulope Morawo, Entomology and Nematology Department; UF/IFAS Extension, Gainesville, FL 32611

The Institute of Food and Agricultural Sciences (IFAS) is an Equal Opportunity Institution authorized to provide research, educational information and other services

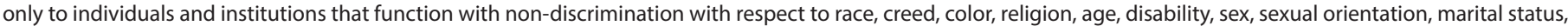

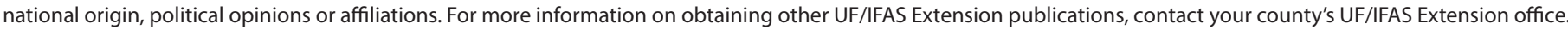
U.S. Department of Agriculture, UF/IFAS Extension Service, University of Florida, IFAS, Florida A \& M University Cooperative Extension Program, and Boards of County Commissioners Cooperating. Nick T. Place, dean for UF/IFAS Extension. 
feminine Greek noun $\tau$ น $\mu$ ' = cut and remains feminine when Latinized with the suffix - $\mathrm{a}$ according to article 30.1.3 of the International Code of Zoological Nomenclature (ICZN) (Pedata, Burckhardt, and Mancini 2012). Because a species-group name must agree in gender with the generic name with which it combined (according to article 31.2. of the ICZN), Macrohomotoma gladiata is the currently accepted name for the species.

\section{Distribution}

Within the continental United States, the reported distribution of all three fig psyllids is limited to California. Homotoma ficusis native to countries in the circum-Mediterranean region, including Portugal, Greece, Israel, and Turkey. Macrohomotoma gladiata has a native range spanning China, India, Indonesia, and Japan, while its introduced range includes Italy, Spain, and Hawaii (Burckhardt, Cho, and Lee 2018). Other than the newly introduced population in California, Trioza brevigenaeis reported only from India (Burckhardt, Cho, and Lee 2018), and Cyprus, where it is an adventive species (Compton et al. 2020).

\section{Description and Life Cycle}

\section{1) Homotoma ficus EGGS}

Homotoma ficus eggs are oval-shaped and laid atop a long filament. They are yellow in color, becoming more intensely so before hatching. Eggs are laid near leaf buds and within bark crevices in small groups (Jerinić-Prodanović 2011). In Turkey, populations overwinter as eggs, from early October to early April (Gencer, Coskuncu, and Kumral 2007).

\section{IMMATURES}

Homotoma ficus immatures pass through five juvenile phases known as instars, and molt (shed their exoskeleton) at the conclusion of each phase. First instars have yellow bodies, red eyes, and brown legs, while fifth instars are between 2.48 and $2.51 \mathrm{~mm}$ in length and are bright green in color with whitish wing pads (Jerinić-Prodanović 2011) (Figure 1).

\section{ADULTS}

Homotoma ficus adults are light green in color when freshly molted, later becoming brownish with age. Their antennae are densely covered with setae (hair-like structures) and have two dark brown terminal segments. Wings are transparent, with some veins outlined in brown, and body length is approximately 3.25 to $3.8 \mathrm{~mm}$ (Jerinić-Prodanović 2011) (Figure 2).

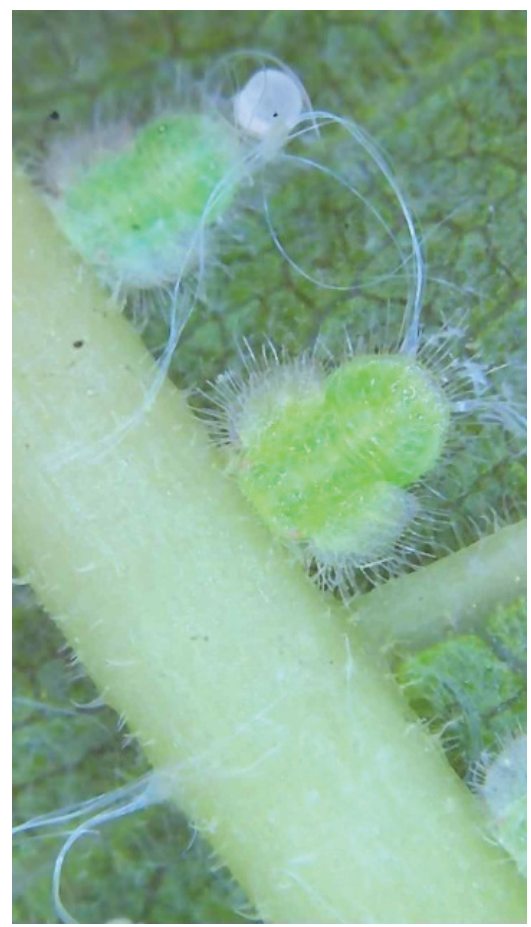

Figure 1. Homotoma ficus L. immatures from France.

Credits: J. A. Roch, inaturalist.org. Image is licensed by Creative Commons (https://creativecommons.org/licenses/by-nc/4.0/)

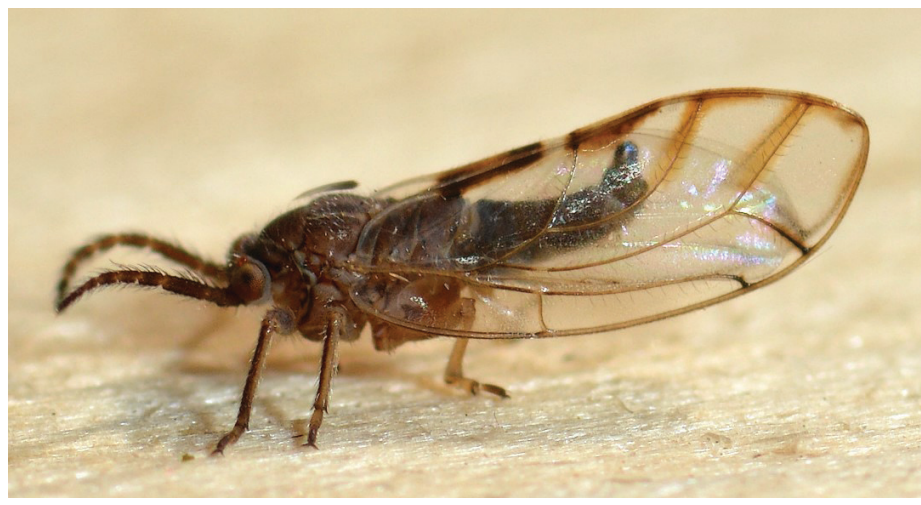

Figure 2. Homotoma ficus L. adult.

Credits: Christophe Quintin, Flickr.com. Image is licensed by Creative Commons (https://creativecommons.org/licenses/by-nc/2.0/)

\section{2) Macrohomotoma gladiata EGGS}

Macrohomotoma gladiata eggs lack a filament and are laid directly on new leaves or withered bracts (modified leaves) in clusters of ten to twenty. They are pale yellow in color (Pedata, Burckhardt, and Mancini 2012).

\section{IMMATURES}

Macrohomotoma gladiata immatures also pass through five instars. They produce white waxy secretions in the form of flakes, which may serve a protective function. The younger instars are orange-brown, while the fifth instar is pale green with brown wing pads (Figure 3 ). The immature colonies feed on young shoots, which may cause shoot deformation or dieback (Pedata, Burckhardt, and Mancini 2012). 


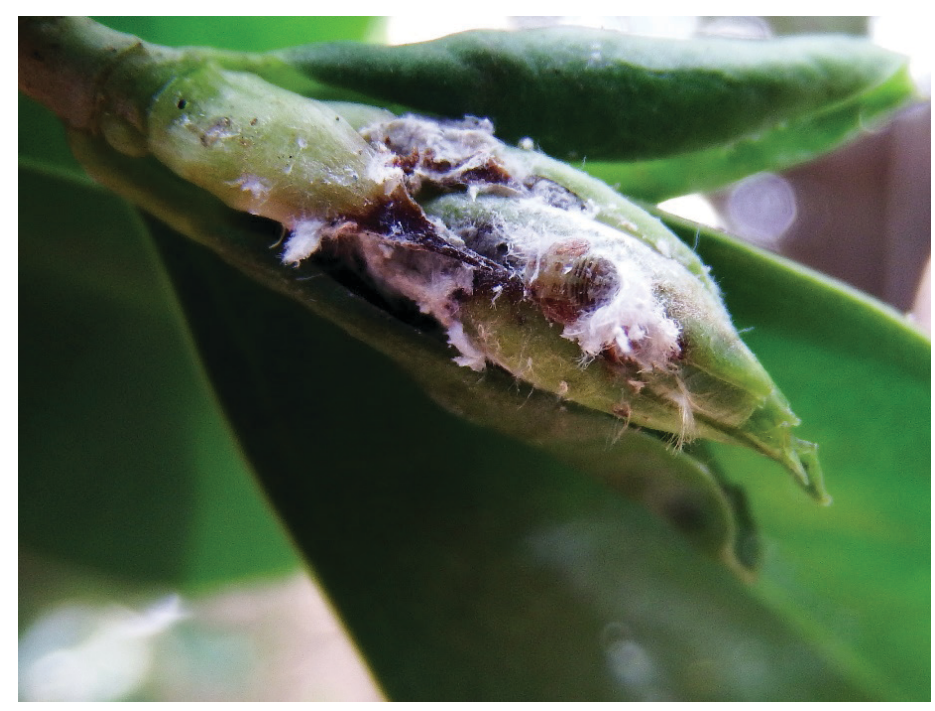

Figure 3. Late instar Macrohomotoma gladiata (Kuwayama) and associated waxy secretions.

Credits: Wallace Chen, inaturalist.org. Image is licensed by Creative Commons (https://creativecommons.org/licenses/by-nc/4.0/)

\section{ADULTS}

Macrohomotoma gladiata adults are 2.0 to $3.0 \mathrm{~mm}$ long, and green to dark brown, with a pale stripe near the base of the forewing. Their antennae have ten segments, and the wings are transparent with several dark spots (Rung 2016) (Figure $4)$.

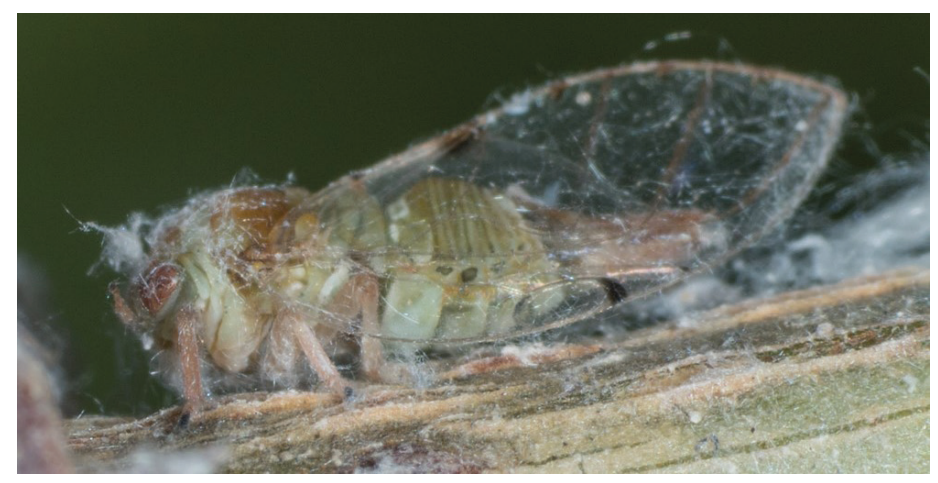

Figure 4. Macrohomotoma gladiata (Kuwayama) adult from California. Credits: Jesse Rorabaugh, inaturalist.org. Image is licensed by Creative Commons (https://creativecommons.org/publicdomain/zero/1.0/)

\section{3) Trioza brevigenae EGGS}

No Trioza brevigenae eggs were observed in initial or follow up California investigations (Hodel et al. 2016, 2020).

\section{IMMATURES}

Trioza brevigenae likely passes through four or five instars. First instars are clear colored, very small, less than $0.5 \mathrm{~mm}$ long, and somewhat mobile. Second instars are orange, oval, $0.65 \mathrm{~mm}$ long and $0.4 \mathrm{~mm}$ wide, and sedentary in a shallow pit. The fourth instar is $1.3 \mathrm{~mm}$ long and resembles the fifth instar but has smaller wing pads and shorter antennae. The fifth and final instar is mobile, $1.9-2.5 \mathrm{~mm}$ long, 0.5-6 mm wide, very narrowly oval to oblong, with wing-pads produced slightly beyond the posterior margins of the very small eyes. The head, thorax, and abdomen are distinguishable, and the dark grayish tan to brownish green body is completely ringed around its margin with a distinctive skirt of densely placed, slender, white- waxy filaments, which are shorter on the sides and unusually long at the cranial and caudal ends (Hodel et al. 2020) (Figure 5). The immatures feed on the undersides of young leaves and stimulate a characteristic longitudinal leaf rolling (along the axis of the midvein) that provides a protective refuge for juveniles and adults (Compton et al. 2020).

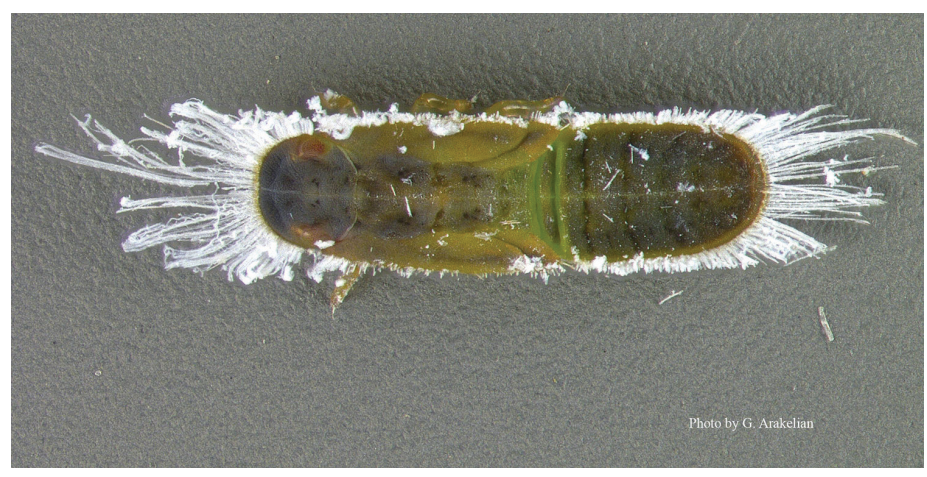

Figure 5. Trioza brevigenae (Mathur), likely fifth instar. Credits: Gevork Arakelian, Los Angeles County Agricultural Commissioner/Weights \& Measures Department

\section{ADULTS}

Trioza brevigenae adults are about 2.6 to $2.8 \mathrm{~mm}$ long, with brownish green heads, red protruding eyes, and an abdomen that turns from green to brown with maturity (Hodel et al. 2016, 2020). The wings are transparent, with no patterning, and extend beyond the tip of the abdomen (Figure 6). Hodel et al. (2016) observed adults of this species raising their abdomens and moving them from side to side in a waggling motion. This may be a mate-finding signal, similar in function to the volatile and vibrational signaling used by other psyllid species (Lubanga et al. 2014).

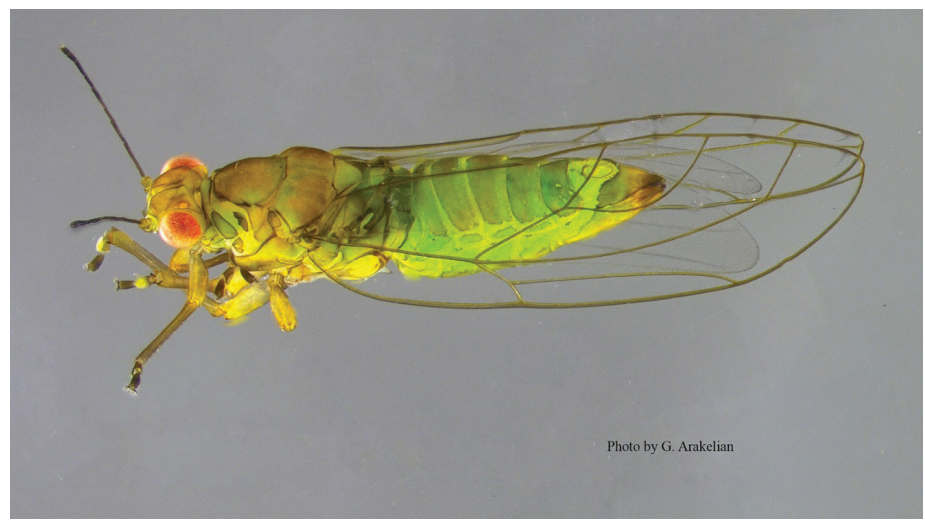

Figure 6. Trioza brevigenae (Mathur) adult. Credits: Gevork Arakelian, Los Angeles County Agricultural Commissioner/Weights \& Measures Department 


\section{Key to Psyllids Found on Ficus sp. in North America}

1. Forewings (Figure 7 ) with vein $\mathrm{R}+\mathrm{M}+\mathrm{Cu}$ trifurcating into $\mathrm{R}, \mathrm{M}$, and $\mathrm{Cu}$; metabasitarsus (segment of tarsus that is the nearest to the body on hind legs, tarsus = leg segment furthest from the body) without dark colored spurs ..... Triozidae .... 21'. Forewings with vein $\mathrm{R}+\mathrm{M}+\mathrm{Cu}$ bifurcating into $\mathrm{R}$ and $\mathrm{M}+\mathrm{Cu}$; metabasitarsus with dark colored spurs. .... Homotomidae...... 3

2. Forewing vein $A_{1}$ with dark spot in basal third; thorax dark maroon-brown dorsally with pale markings; antennae mostly pale with dark tips; on Ficus aurea.... . Trioza myresae

2. Forewing vein $A_{1}$ with no color pattern; thorax entirely green to brown dorsally; antennae mostly dark, without a contrastingly pale mid-section; on Ficus microcarpa and possibly other Ficus species. ... . Trioza brevigenae

\section{Pterostigma present in forewing (Figure 7); antennal} flagellum (third to final segments from head) not thickened and densely setose (bearing stiff structures resembling hair or bristles) .... Macrohomotominae: Macrohomotoma gladiata

3. Pterostigma absent; antennal flagellum thickened and densely setose. . . . . Homotominae: Homotoma ficus

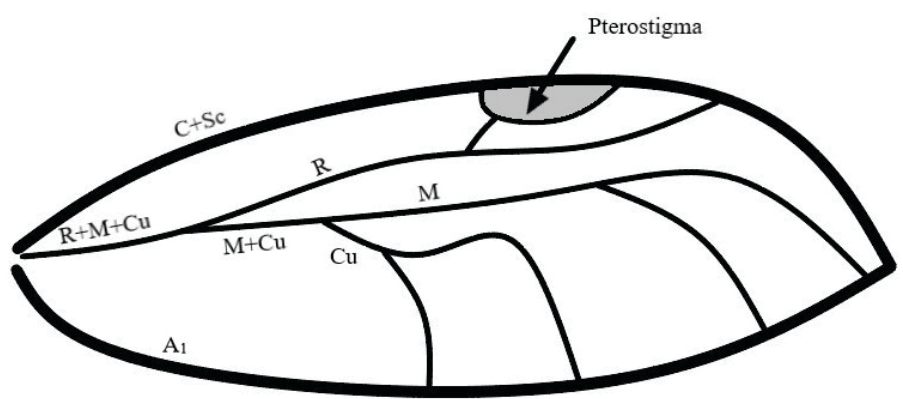

Figure 7. Simplified view of a psyllid forewing, with the leading edge facing upwards. Veins mentioned in the key are labelled.

Credits: Figure adapted from Rung (2016), and Halbert and Burckhardt (2020)

When a determination is reached using the above key, check the specimen against photos provided in the "Description and Life History" section. There are many introduced and native psyllid species in North America, and it is possible that one may be found incidentally on Ficus. Incidental species are not included in the key. For literature on Florida psyllid fauna, including Trioza myresae (Burckhardt and Halbert) which uses Ficus aurea (the native Florida stranger fig) as its host plant, please see Halbert and Burckhardt (2020).

\section{Hosts}

Individual psyllid (Hemiptera: Psylloidea) species typically have narrow host ranges. For this group of insects, Burckhardt et al. (2014) proposed that the term "host-plant" should only be used for a plant on which a psyllid species completes its immature to adult life cycle. By this narrow standard, the host plant of Homotoma ficus is Ficus carica (Jerinić-Prodanović 2011), while both Macrohomotoma gladiata and Trioza brevigenae utilize Ficus microcarpa in California (Figures 8 and 9).

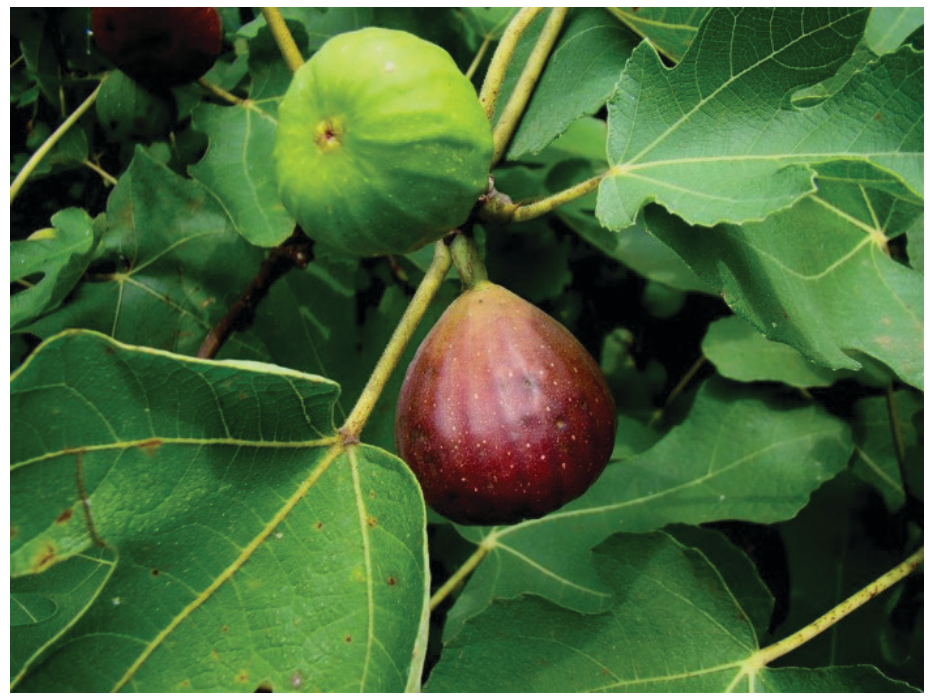

Figure 8. Fruit and leaves of Ficus carica.

Credits: Doug McAbee, Flickr.com. Image is licensed by Creative Commons (https://creativecommons.org/licenses/by/2.0/)

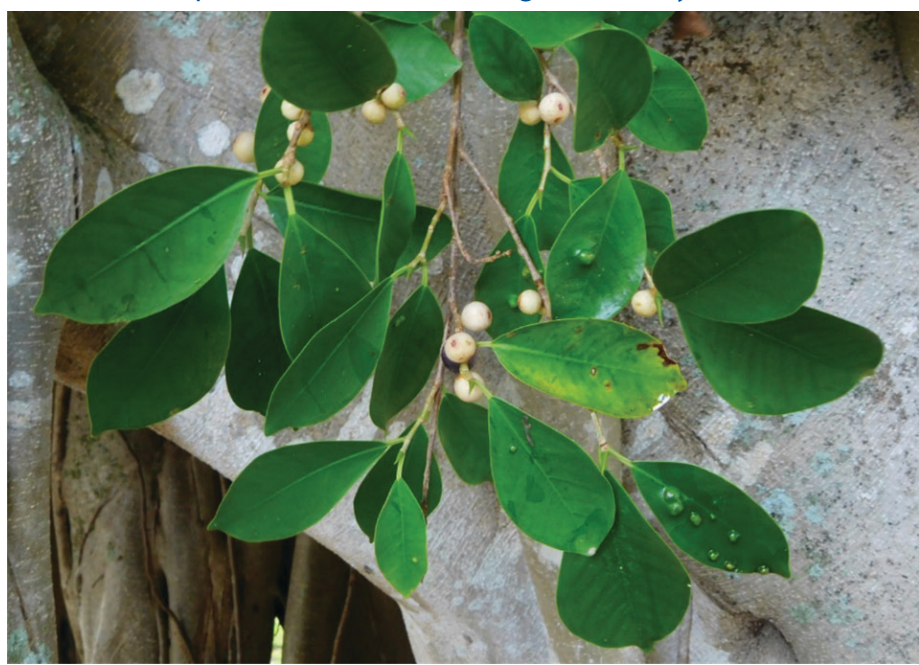

Figure 9. A Ficus microcarpa branch. The leaf galling is caused by another adventive insect species, the wasp Josephiella microcarpae (Beardsley \& Rasphus).

Credits: Alexander Tasi, UF/IFAS

\section{Economic Importance}

Psyllids as a group include a number of important agricultural pest species, such as the pear psyllid, Cacopsylla pyricola (Förster), Asian citrus psyllid Diaphorina citri 
Kuwayama, and the potato psyllid Bactericera cockerelli (Šulc), all of which transmit damaging plant pathogens (Triplehorn and Johnson 2005). However, of the three Ficus associated psyllid species found in California, only Homotoma ficus feeds on a food crop plant. Its host plant, the common fig, is grown on over 2468 ha of land in the state and produces a farm gate value of more than 29 million dollars annually (CAS 2017). However, in California, H. ficus does not seem to be a serious pest on either orchard or ornamental landscape edible fig trees. It generally is also insignificant as a pest in its native range, although damage may be locally noticeable if sufficiently high psyllid populations build up (Gencer, Coskuncu and Kural 2007).

Ficus microcarpa, on the other hand, is typically planted as an ornamental, and is a relatively common street tree in south and central Florida (Figure 10). Urban and suburban trees can provide a variety of benefits that are not easily translatable to a fixed dollar value, including increased quality of life, habitat for wildlife, and energy savings from shade (Hilbert et al. 2019). Furthermore, these benefits also are balanced against a mix of potential costs, including damage to property and infrastructure due to growth or storms. If Macrohomotoma gladiata or Trioza brevigenae were to arrive in Florida, they would likely have a significant and aesthetically noticeable effect on their host tree, but the economic impact would be difficult to measure in concrete terms. Fortunately, in California so far, their damage is mostly minor, is visible only when viewed closely, and overall tree health is not much affected. However, Ficus microcarpa often is used as a pruned or clipped hedge, and in these cases M. gladiata can cause patchy but conspicuous defoliation and twig dieback (DR Hodel 2021, personal communication, 11 February 2021).

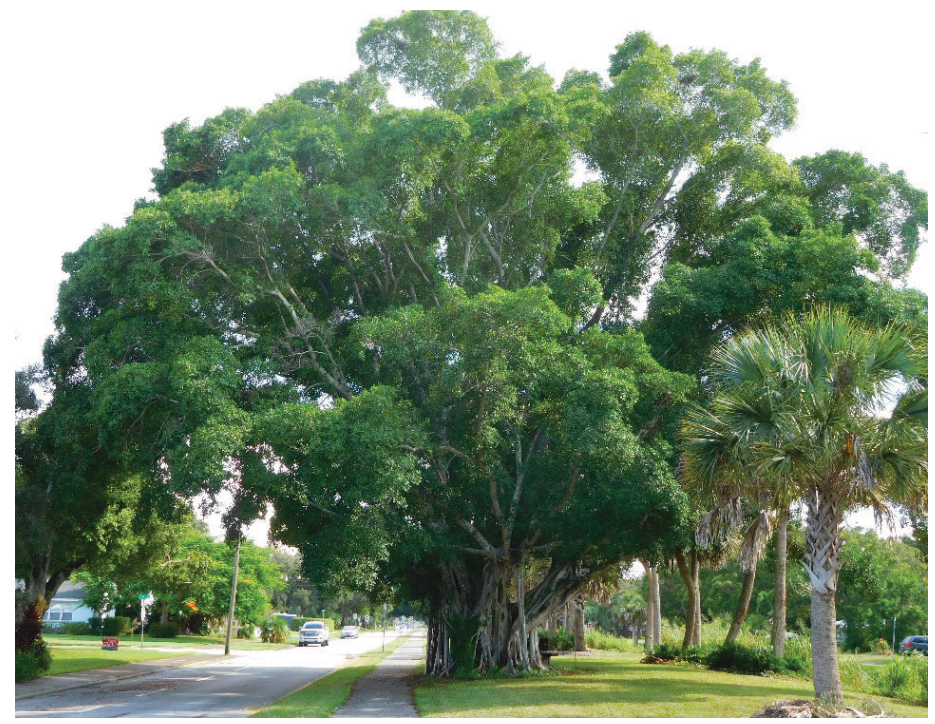

Figure 10. Ficus microcarpa (center) grown as a street tree in Vero Beach, Florida.

Credits: Alexander Tasi, UF/IFAS

\section{Management}

An integrated pest management approach (monitoring, biological, chemical, and/or cultural control) would likely be the most effective strategy for mitigating the effects of these three psyllids. In California, damage caused the psyllids is generally well tolerated by their host plants, and chemical control is needed only as a rare last resort. On the other hand, management in Florida would depend on pest status, if any, if these insects were to become established. While there is no formal biological control program in the United States focused on any of these psyllid species, several natural enemies were found to provide some level of control against Macrohomotoma gladiata in Spain, including the parasitic wasp Prionomitus mitratus (Dalman) (Hymenoptera, Encyrtidae) and the predatory "minute pirate bug" Anthocoris nemoralis (Fabricius) (Hemiptera, Anthocoridae) (Laborda et al. 2015). The authors also found that botanical oils were effective at reducing the density of immatures on new growth. Lastly, finding more insect resistant Ficus cultivars may be the best long-term method of achieving a sustainable balance between the costs of psyllid control and the benefits of healthier street trees and more productive crop plants.

\section{Selected References}

Burckhardt D. 1994. Generic key to Chilean jumping plantlice (Homoptera: Psylloidea) with inclusion of potential exotic pests. Revista Chilena de Entomología 21: 57-67.

Burckhardt D, Cho G, Lee S. 2018. Moriphila furva gen. and sp. nov. (Hemiptera: Psylloidea: Homotomidae), a new jumping plant-louse from Korea associated with Morus australis (Moraceae). Zootaxa 4444: 299-315. https://doi. org/10.11646/zootaxa.4444.3.5

Burckhardt D, Ouvrard D, Queiroz D, Percy, D. 2014. Psyllid host-plants (Hemiptera: Psylloidea): resolving a semantic problem. Florida Entomologist 97: 242-246. https://doi.org/10.1653/024.097.0132

CAS. 2017. California Agriculture Statistic Review, 2016 2017. California Department of Food and Agriculture, Sacramento, CA. https://www.cdfa.ca.gov/Statistics/ PDFs/2016-17AgReport.pdf

Compton SG, Stavrinides M, Kaponas C, Thomas PJ. 2020. No escape: most insect colonisers of an introduced fig tree in Cyprus come from the plant's native range. Biological Invasions 22: 211-216. https://doi.org/10.1007/ s10530-019-02132-4 
Dara SK, Hodel DR. 2015. Weeping fig thrips (Thysanoptera: Phlaeothripidae) in California and a review of its biology and management options. Journal of Integrated Pest Management 6: 2. https://doi.org/10.1093/jipm/pmv001

Gencer NS, Coskuncu KS, Kumral NA. 2007. The colonization preference and population trends of larval fig psylla, Homotoma ficus L. (Hemiptera: Homotomidae). Journal of Pest Science 80: 1-8. https://doi.org/10.1007/ s10340-006-0140-y

Halbert SE, Burckhardt D. 2020. The psyllids (Hemiptera: Psylloidea) of Florida: newly established and rarely collected taxa and checklist. Insecta Mundi 0788: 1-88.

Hilbert DR, Koeser AK, Roman LA, Hamilton K, Landry SM, Hauer RJ, Campanella H, McLean D, Andreu M, Perez H. 2019. Development practices and ordinances predict inter-city variation in Florida urban tree canopy coverage. Landscape and Urban Planning 190: 103603. https://doi. org/10.1016/j.landurbplan.2019.103603

Hodel DR, Arakelian G, Ohara LM, Wilen C, Dara SK. 2016. The Ficus leaf-rolling psyllid. PalmArbor 2: 1-9.

Hodel DR, Komen J, Ohara LM, Arakelian A, RugmanJones PF. 2020. Another look at the Ficus leaf-rolling psyllid. PalmArbor 2020-15: 1-31. https://ucanr.edu/sites/ HodelPalmsTrees/files/337566.pdf

Hollis D, Broomfield PS. 1989. Ficus-feeding psyllids (Homoptera), with special reference to the Homotomidae. Bulletin of the British Museum of Natural History, Entomology 58: 131-183.

Jerinić-Prodanović D. 2011. The first finding of the fig psylla Homotoma ficus L (Hemiptera, Psylloidea, Homotomidae) in Serbia. Pesticidi i Fitomedicina 26: 205-212. https://doi.org/10.2298/PIF1103205J

Johnson NF, Triplehorn CA. 2005. Borror and DeLong's Introduction to the Study of Insects, $7^{\text {th }}$ ed. Thompson Brooks/Cole, Belmont, CA.

Ko CC, Shih YT, Schmidt S, Polaszek A. 2015. A new species of Encarsia (Hymenoptera, Aphelinidae) developing on ficus whitefly Singhiella simplex (Hemiptera, Aleyrodidae) in China and Taiwan. Journal of Hymenoptera Research 46: 85-90. https://doi.org/10.3897/JHR.46.5155
Kuwayama S. 1908. Die Psylliden Japans. I. Transactions of the Sapporo Natural History Society 2: 149-189.

Laborda R, Galán-Blesa J, Sánchez-Domingo A, Xamaní P, Estruch VD, Selfa J, Guerrieri E, Rodrigo E. 2015. Preliminary study on the biology, natural enemies and chemical control of the invasive Macrohomotoma gladiata (Kuwayama) on urban Ficus microcarpa L. trees in Valencia (SE Spain). Urban Forestry \& Urban Greening 14:123-128. https://doi.org/10.1016/j.ufug.2014.12.007

Lubanga UK, Guédot C, Percy DM, Steinbauer MJ. 2014. Semiochemical and vibrational cues and signals mediating mate finding and courtship in Psylloidea (Hemiptera): A synthesis. Insects 5: 577-595. https://doi.org/10.3390/ insects5030577

Pedata PA, Burckhardt D, Mancini D. 2012. Severe infestations of the jumping plant-louse Macrohomotoma gladiata, a new species for Italy in urban Ficus plantations. Bulletin of Insectology 65:95-98.

Rung A. 2016. A new pest of ficus in California: Macrohomotoma gladiata Kuwayama, 1908 (Hemiptera: Psylloidea: Homotomidae), new to North America. Check List 12: 1882. https://doi.org/10.15560/12.3.1882 